\title{
Affinity-purified human Interleukin $I$ is cytotoxic to isolated islets of Langerhans
}

\author{
T. Mandrup-Poulsen', K. Bendtzen'2, J. Nerup ${ }^{1}$, C. A. Dinarello ${ }^{3}$, M. Svenson² and J. H. Nielsen ${ }^{4}$ \\ ${ }^{1}$ Steno Memorial Hospital, Gentofte, Denmark and ${ }^{2}$ Laboratory of Medical Immunology, Rigshospitalet, University Hospital of Copenhagen, \\ Copenhagen, Denmark and '3 Department of Medicine, Tufts University School of Medicine, Boston, Massachusetts, USA and \\ ${ }^{4}$ Hagedorn Research Laboratory, Gentofte, Denmark
}

\begin{abstract}
Summary. Addition of highly purified human Interleukin-1 to the culture medium of isolated rat islets of Langerhans for 6 days led to $88 \%$ inhibition of glucose-induced insulin-release, reduction of islet contents of insulin and glucagon to $31 \%$ and $8 \%$ respectively, and disintegration of the islets. These effects were dose-dependent and reproducible when using three different Interleukin-1 preparations. Highly purified human Interleukin-2, Lymphotoxin, Leucocyte Migration Inhibitory Factor and Macrophage Migration Inhibitory
\end{abstract}

Factor were ineffective. These findings suggest that Interleukin-1 may play an important role in the molecular mechanisms underlying autoimmune B-cell destruction leading to Type 1 (insulin-dependent) diabetes mellitus.

Key words: Autoimmunity, pancreatic B cells, cytotoxicity, Interleukin-1, lymphokines, macrophages, pancreatic islets pathogenesis, Type 1 (insulin-dependent) diabetes mellitus.
Type 1 (insulin-dependent) diabetes mellitus is a clinical syndrome resulting from a highly selective destruction of pancreatic B cells. Circumstantial evidence indicates that the humoral and cellular immune abnormalities observed in the period preceding and following clinical onset of Type 1 diabetes mellitus are involved in the pathogenesis of the disease [1]. The mechanism by which the autoimmune process destroys the target cell is unknown.

Activated mononuclear cells produce and secrete a number of biologically potent antigen-non-specific mediators (cytokines) essential for the cellular interplay of the immune response [2]. We have previously reported that supernatants of activated peripheral blood mononuclear cells (MNC), when added to isolated islets of Langerhans in vitro, markedly decreased the release of insulin and the content of insulin and glucagon in the islets $[3,4]$. This effect was dose-dependent and appeared cytotoxic as judged by light [3] and electronmicroscopic morphology of the islet cells [4].

The aim of the present study was to identify the cytokine(s) responsible for these effects by testing some highly purified cytokine preparations, i.e. Interleukin(IL)-1 and -2, Lymphotoxin and Macrophage- and Leucoyte Migration Inhibitory Factors. We report that only preparations with IL-1 activity can reproduce the effects of the crude cytokine-rich supernatants previously described $[3,4]$.

\section{Subjects and methods}

\section{Islet isolation and culture}

Rat islets were isolated from collagenase-treated pancreata of male Wistar rats of 90-120 g (Møllegaard, Lille Skensved, Denmark) and precultured for 7 days [5]. The precultured isolated islets were pooled, washed once in medium RPMI 1640 (Flow Laboratories, Irvine, Scotland) and distributed randomly in plastic Petri dishes (Falcon, Oxnard, California, USA) at a concentration of 10 islets $/ \mathrm{ml}$ in medium RPMI 1640 supplemented with $20 \mathrm{mmol} / 1$ Hepes buffer, $11 \mathrm{mmol} / 1$ glucose, $100,000 \mathrm{IU} / \mathrm{l}$ penicillin, $100 \mathrm{mg} / \mathrm{l}$ streptomycin and $0.5 \%$ normal human serum pool. The islets were incubated free-floating for 6 days in $90 \%$ humid atmosphere at $37{ }^{\circ} \mathrm{C}$ with or without addition of highly purified cytokine preparations. After 6 days in culture (i) representative photomicrographs were taken in an inverted microscope (Leitz, Wetzlar, FRG), (ii) $300 \mu$ l culture medium was sampled for determination of insulin by RIA [6] using rat insulin as standard (NOVO Research Institute, Bagsvaerd, Denmark), and (iii) islets were harvested, washed once in distilled water and sonicated for the determination of islet contents of insulin [6] and glucagon (NOVO RIA kit). The following scoring system was used for the evaluation of the light microscopic islet morphology: - : morphology indiscernible from control islets, $(+)$ : a few islets disintegrated, $+:$ all islets disintegrated.

All experiments were carried out in duplicate. Only experiments performed with different islet isolates were included as separate observations.

\section{Preparation of highly purified cytokines}

Purified human Interleukin I (IL-1). Human IL-1 was purified from the supernatants of adherent human blood monocytes as previously described [7]. Briefly, the supernatant was purified by immunoadsorp- 
Table 1. Effects of highly purified human cytokines on insulin-release (ng/10 islets/6 days), insulin-content (ng/islet), glucagon-content (ng/islet) and morphology of isolated rat islets of Langerhans

\begin{tabular}{|c|c|c|c|c|c|c|c|c|}
\hline \multirow[t]{2}{*}{ Cytokine preparations } & \multicolumn{4}{|c|}{ Experiment 1} & \multicolumn{4}{|c|}{ Experiment 2} \\
\hline & $\begin{array}{l}\text { Insulin- } \\
\text { release }\end{array}$ & $\begin{array}{l}\text { Insulin- } \\
\text { content }\end{array}$ & $\begin{array}{l}\text { Glucagon- } \\
\text { content }\end{array}$ & $\begin{array}{l}\text { Islets } \\
\text { dissolved }\end{array}$ & $\begin{array}{l}\text { Insulin- } \\
\text { release }\end{array}$ & $\begin{array}{l}\text { Insulin- } \\
\text { content }\end{array}$ & $\begin{array}{l}\text { Glucagon- } \\
\text { content }\end{array}$ & $\begin{array}{l}\text { Islets } \\
\text { dissolved }\end{array}$ \\
\hline Medium RPMI 1640 & 2053 & 10.6 & 1.42 & - & 2033 & 12.9 & 0.77 & - \\
\hline $\mathrm{IL}-2,30 \mathrm{U} / \mathrm{ml}$ & 1970 & 14.1 & 1.93 & - & 2325 & 14.9 & 1.00 & - \\
\hline $\begin{array}{l}\text { Lymphotoxin }^{\mathrm{a}} \\
1500 \mathrm{U} / \mathrm{ml}\end{array}$ & 1690 & 22.1 & 2.43 & - & 2318 & 16.9 & 1.82 & - \\
\hline $\begin{array}{l}\text { Lymphotoxin }^{b} \\
20,000 \mathrm{U} / \mathrm{ml}\end{array}$ & 1951 & 21.0 & 0.61 & - & 1997 & 20.9 & 0.44 & - \\
\hline LIF (82DB01), $145 \mu \mathrm{l} / \mathrm{ml}$ & 1901 & 23.0 & 2.14 & - & 2287 & 18.4 & 1.08 & - \\
\hline LIF (WG3), $145 \mu \mathrm{l} / \mathrm{ml}$ & NT & NT & NT & NT & 2421 & 20.4 & 0.79 & - \\
\hline $\mathrm{MIF}, 30 \mu \mathrm{l} / \mathrm{ml}$ & 1421 & 17.0 & 0.68 & - & NT & NT & NT & NT \\
\hline $\begin{array}{l}\text { IL-1 }\left(17,500 \mathrm{M}_{\mathrm{r}}, 094\right) \\
175 \mathrm{U} / \mathrm{ml}\end{array}$ & 199 & 6.9 & 0.14 & + & 128 & 3.2 & 0.06 & + \\
\hline $\begin{array}{l}\text { IL-1 }\left(17,500 \mathrm{M}_{\mathrm{r}}, 008\right) \\
150 \mathrm{U} / \mathrm{ml}\end{array}$ & NT & NT & NT & NT & 164 & 3.3 & 0.05 & + \\
\hline $\begin{array}{l}\text { IL-1 }\left(35,000-40,000 \mathrm{M}_{\mathrm{r}}\right. \\
75 \mathrm{U} / \mathrm{ml}\end{array}$ & 370 & 10.3 & 0.21 & + & 190 & 3.3 & 0.07 & + \\
\hline
\end{tabular}

Results are presented as means of duplicate experiments. NT: not tested

a Highly purified Lymphotoxin

b Crude Lymphotoxin
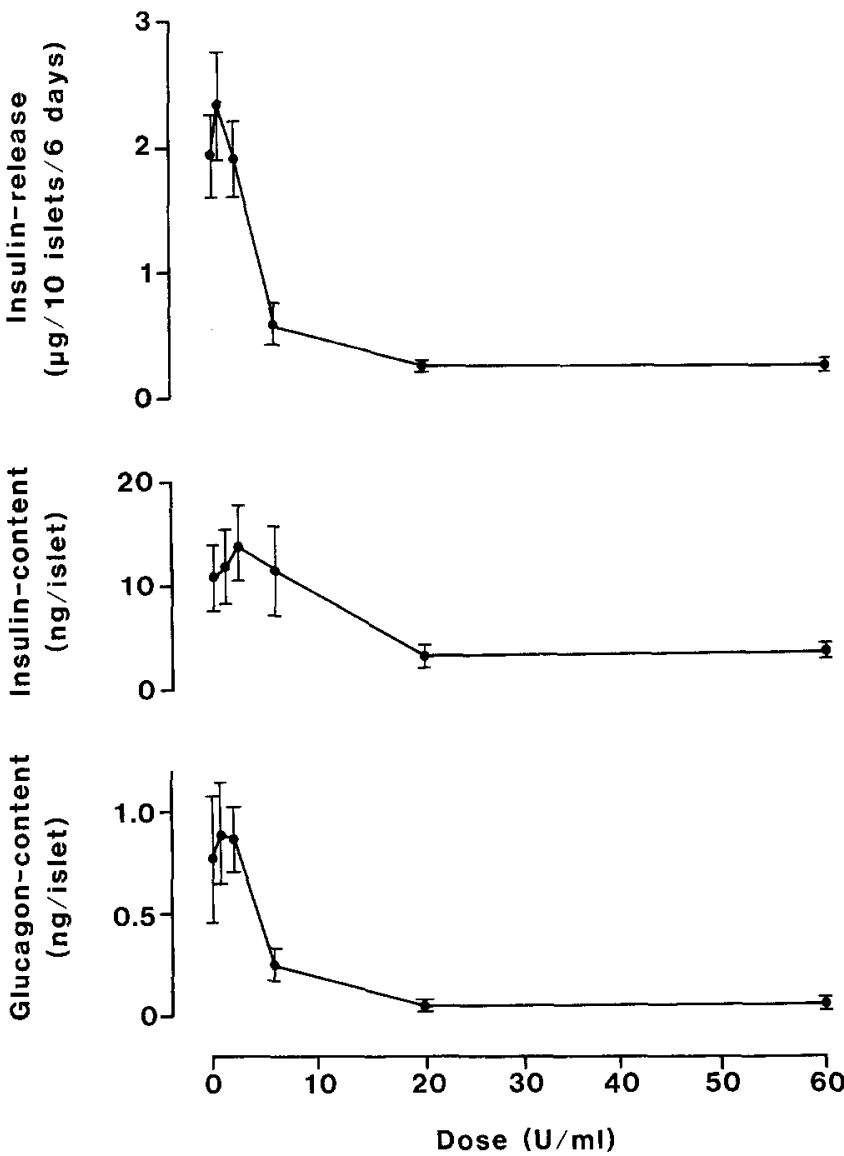

Fig. 1. Dose-response relationship between increasing doses of purified human IL-1 $\left(17,500 \mathrm{M}_{1}, 094\right)$ and insulin-release (upper panel), insulin content (middle panel) and glucagon content in isolated rat islets in culture for 6 days $(n=3)$ tion [8], gel-filtration and chromatofocusing. Following the immunoadsorption step, there was a peak of IL-1 activity at $35,000-40,000 \mathrm{M}_{\mathrm{r}}$ and another broader peak between 15,000 and $20,000 \mathrm{M}_{\mathrm{r}}$. Using ${ }^{35} \mathrm{~S}$-methionine and ${ }^{3} \mathrm{H}$-leucine intrinsic labelling, SDS-PAGE and fluorography revealed the 3 isoelectric points of human IL-1 with the predominant $\mathrm{pI} 7$ form appearing as a homogeneous band at $17,500 \mathrm{M}_{\mathrm{r}}$. Amino acid sequence of this material revealed radioactive amino acids corresponding to the positions of methionine 136 and leucine 142,145 and 147 of the pI 7 IL- 1 sequence predicted by the cDNA [9]. The specific activities of the preparations were: $35,000-40,000 \mathrm{M}_{\mathrm{r}} \mathrm{IL}-1: 500 \mathrm{U} / \mathrm{ml} ; 17,500 \mathrm{M}_{\mathrm{r}} \mathrm{IL}-1: 1000 \mathrm{U} / \mathrm{ml}$ (batch 008) and $1200 \mathrm{U} / \mathrm{ml}$ (batch 094).

Purified human Interleukin 2 (IL-2). Highly purified human IL-2 was obtained by affinity-purification of supernatants of the human Tcell line Jurkat [10] induced by phytohaemagglutinin (PHA) and phorbol myristate acetate (PMA). 1 unit of IL-2 $=3.2 \mathrm{ng}$ protein [10]. The preparation was kindly provided by Richard Robb, E.I. du Pont de Nemosins \& Company, Wilmington, Delaware, USA. The specific activity was $1000 \mathrm{U} / \mathrm{ml}$.

Purified human Lymphotoxin. Crude supernatants of the human RPMI 1788 B-lymphoblastoid cell line were concentrated, dialysed and partially purified by Blue Agarose and Con-A Sepharose chromatography. The preparations had a specific activity of $10^{5}$ units $/ \mathrm{ml}$, and were kindly provided by Dr. A. Khan, The Cancer Center at Wadley Institutes, Dallas, Texas, USA.

Crude human Lymphotoxin. Crude lymphotoxin was derived from supernatants of the human B-lymphoblastoid cell line RPMI 1788 and kindly provided by Dr. H. van den Berg, Organon, Oss, The Netherlands (activity $15 \times 10^{4}$ units $/ \mathrm{ml}$ ).

Human Macrophage Migration Inhibitory Factor (MIF). MIF was a partially purified MIF preparation prepared by affinity chromatography and isoelectric focusing personal communication, kindly provided by Dr. A. Khan, The Cancer Center of Wadley Institutes, Dallas, Texas, USA.

Leucocyte Migration Inhibitory Factor (LIF). LIF was prepared by ultrafiltrates of supernatants of the human RPMI 1788 B-lymphoblastoid cell line. LIF (82DB01) was kindly provided by Organon, Oss, The Netherlands, and LIF (WG 3) by Dr. B.Papermaster, Columbia, Missouri, USA. 


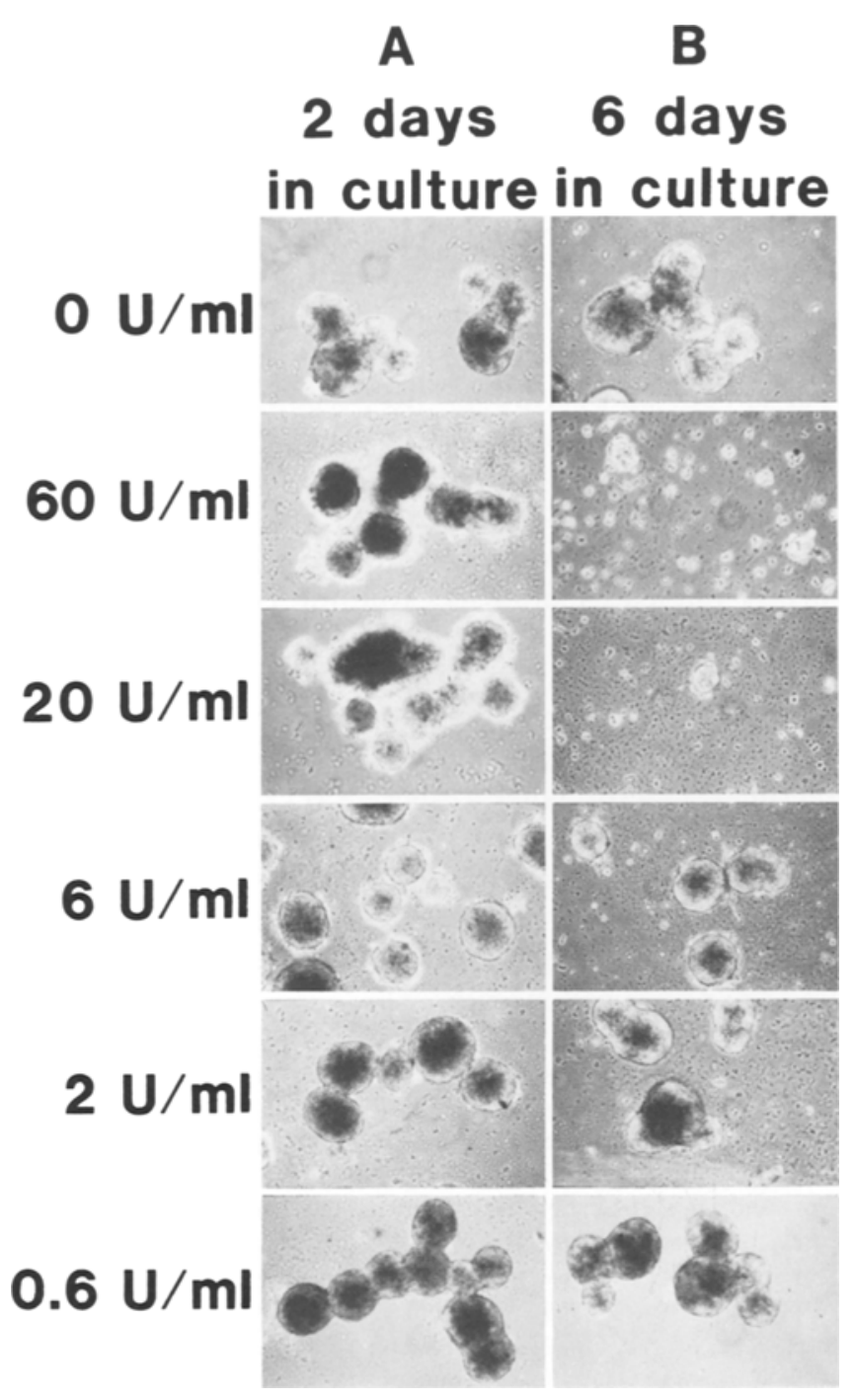

Fig. 2. Light microscopic morphology of rat islets incubated with 0 , $60,20,6,2$ or $0.6 \mathrm{U} / \mathrm{ml}$ IL-1 $\left(17,500 \mathrm{M}_{\mathrm{r}}, 094\right)$ for 2 (A) or 6 (B) days. Magnification $100 \times$

Table 2. Effects of interleukin 1 on non-lymphoid cells

IL-1 - stimulates hepatocytes to produce acute phase proteins [12]

- induces fever by effects on hypothalamic cells (12)

- induces muscle cells to release aminoacids (12)

stimulates fibroblasts to proliferate and to produce prostaglandins and collagenase (12)

- activates chondrocytes to degrade cartilage matrix (12)

- stimulates human bone-cells to proliferate (12)

stimulates astroglial cells to proliferate (14)

\section{Results}

\section{Screening of highly purified cytokine preparations for effects on islet function or morphology}

All cytokine preparations were tested in supramaximal doses. Only when cytokine preparations with IL-1 activity were added to the islet cultures were the accumulat- ed glucose-induced insulin-release and islet contents of insulin and glucagon decreased and islet morphology disintegrated (Table 1). Consistent results were obtained employing three different IL-1 preparations.

\section{Dose-response experiments with purified IL-1}

When incubated with increasing concentrations of IL-1, both accumulated glucose-stimulated insulin-release from the rat islets and contents of islet insulin and glucagon were reduced (Fig. 1). The insulin-release was reduced to approximately $12 \%$ of the insulin-release in IL-1-free medium, and it can be estimated from the dose-response curve that a $50 \%$ reduction in insulin-release was accomplished at an IL-1 concentration of approximately $5 \mathrm{U} / \mathrm{ml}$. Higher IL-1 concentrations were necessary to induce a $50 \%$ reduction in islet insulin content. The glucagon content was reduced to approximately $8 \%$, and a $50 \%$ reduction was seen at an IL-1 concentration of about $5 \mathrm{U} / \mathrm{ml}$.

Light microscopy showed unequivocal disintegration of the islet morphology in all experiments with IL-1 concentrations of $60 \mathrm{U} / \mathrm{ml}$ and $20 \mathrm{U} / \mathrm{ml}$ (Figs. 1 and 2). At an IL-1 concentration of $6 \mathrm{U} / \mathrm{ml}$ islet morphology in the light microscope was normal in spite of a reduction of the insulin-release to about $25 \%$ of normal.

\section{Discussion}

We have previously shown that crude supernatants of activated MNC markedly reduced the insulin-release and contents of insulin and glucagon in isolated islets of Langerhans and disintegrated normal light- and electronmicroscopical morphology of the islets $[3,4]$.

Screening of several cytokines showed that effects comparable to those observed with crude supernatants were only seen using highly purified IL-1 preparations. The effects of interferons were not tested in this study since in a recent study human lymphoblastoid interferon did not alter glucose-stimulated insulin-release or islet contents of insulin or DNA in isolated human islets [11]. In that study glucose-stimulated proinsulin-biosynthesis was inhibited, but this was probably due to a general inhibitory effect by interferon on cell protein biosynthesis [11].

The concomitant reduction of insulin-release and insulin content in islets induced by IL-1 indicate that IL-1 either inhibits insulin-biosynthesis or has a cytotoxic effect on B cells in the islets. Measurements of insulin-biosynthesis was not performed, but disintegration of normal islet morphology paralleled the impairment of islet function (Fig. 2), strongly suggesting a direct cytotoxic effect. Insulin-release and glucagoncontent were the most sensitive of the parameters studied to reveal the deleterious effects of IL-1 on islet function. The cytotoxic effect was not specific to B cells after 7 days in culture in the presence of IL-1, since the glu- 
cagon content was also markedly reduced in islets treated with IL-1 preparations.

The degree of purification of the IL-1 preparations and the fact that three different IL-1 preparations impaired islet function and morphology to a similar degree makes it unlikely that other substances than IL-1 are responsible for the observed effects. However, we cannot entirely exclude a synergistic effect of IL-1 and other substances present in the crude cytokine preparations. Presently, we are unable to determine in absolute terms the strength of the IL-1 preparations investigated. Roughly estimated IL-1 seems to be directly cytotoxic to rat islet cells in concentrations that will activate lymphoid cells, i.e. molar concentrations about $10^{-12}$ [2]. The unlikely possibility that the cytotoxic effect of IL-1 is indirect, i.e. mediated by non-endocrine cells in the cultured islets cannot be excluded at present.

Human IL-1 is a $17,500 \mathrm{M}_{\mathrm{r}}$ polypeptide synthesized primarily in blood monocytes and tissue macrophages [12]; it has recently been cloned and sequenced [9]. IL-1 secreted by activated macrophages is necessary for the activation of antigen-specific T-helper-lymphocytes in addition to MHC-restricted antigen presentation [13]. IL-1 therefore plays a crucial role in the initiation of the immune response. In addition, IL-1 exerts important effects on non-lymphoid cells (Table 2). However, a cytotoxic effect of IL-1 on normal cells has not previously been reported.

The finding that a macrophage factor, IL-1, is cytotoxic to islet cells may introduce a new concept in the understanding of the immune-pathogenesis of Type 1 diabetes. Macrophages are numerous in the insulitis infiltrate in the spontaneously insulin-dependent diabetic BB-rat [15] and in Type 1 diabetic patients [16]. Activated macrophages have been reported to decrease glucose-stimulated insulin-release [17] and to be cytotoxic to syngeneic cultured mouse islets of Langerhans [18]. Silica particles block macrophage function either by inducing release and subsequent depletion of IL-1 or by chronically modifying the macrophages [19]. Intraperitoneal and intravenous administration of silica to BB rats at an age where insulitis or diabetes is not present almost completely prevents the development of diabetes [19]. In addition, silica administration prevents the rejection of islet allografts in rats [20]. The production of IL-1 by acutely diabetic BB rat splenic macrophages is normal [21], although IL-2 production by spleen lymphocytes in $\mathrm{BB}$ rats and by blood MNC in Type 1 diabetic patients of recent onset may be decreased [21, 22]. Recently, basal and stimulated IL-1 production from peripheral blood monocytes from Type 1 diabetic patients was found to be increased at the time of diagnosis (A. Luger, personal communication), but normal or decreased after longer diabetes duration [23].

The listed evidence calls attention to the role of macrophages and IL-1 in the pathogenesis of Type 1 diabetes mellitus. This concept may be generalized to other autoimmune endocrinopathies associated with Type 1 diabetes mellitus, e.g. primary myxedema, Hashimoto's thyroiditis, idiopathic Addison's disease, hypogonadotropic hypogonadism in females and possibly pernicious anemia.

It should be noted that activated $\mathrm{T}$ cells can boost and maintain the production and secretion of IL- 1 in macrophages by the secretion of interferon- and other macrophage-activating lymphokines (MAFs) [24]. This positive feedback between macrophage and $T$ cell is important for amplification and perpetuation of the production of IL-1 needed for continued activation of the immune-response. However, IL-1 production may further be envisaged to play an important role in the molecular mechanism underlying $\mathrm{B}$ cell destruction in Type 1 diabetes mellitus as follows: Specifically sensitized T-lymphocytes home to the B cell core of the islets. They are activated to produce lymphokines by the recognition of liberated B cell antigens presented by macrophages. The MAFs produced by the $T$ cells stimulate recruited macrophages to secrete IL-1, thereby increasing IL-1 concentrations in the intercellular space between islet cells to cytotoxic levels. The preferential destruction of B cells may be facilitated by the separate vascular supply and drainage of the $B$ cell rich islet core and the non $\mathrm{B}$ cell mantle [25].

Acknowledgements. The authors thank Ms. S. Grinderslev and Ms. S. Meldgaard for devoted technical assistance, and Ms. A. Rafn for preparing the manuscript. Dr. Mandrup-Poulsen is the recipient of a fellowship from the Michaelsen Foundation and financial support from the Danish Diabetes Association (Diabetesforeningen, Landsforeningen for Sukkersyge), P. Carl Petersens Foundation, and King Christian Xth Foundation. Dr. Bendtzen received financial support from the Danish Medical Research Council and the Danish Cancer Society.

\section{References}

1. Nerup J, Lernmark $\AA$, Scott J (1984) Autoimmunity. In: Gupta S, ed: Immunology of clinical and experimental diabetes. Plenum Book Company, New York, pp 351-367

2. Rocklin RE, Bendtzen K, Greineder D (1980) Mediators of immunity: Lymphokines and monokines. Adv Immunol 29: 55-136

3. Mandrup-Poulsen T, Bendtzen K, Nielsen JH, Bendixen G, Nerup J (1985) Cytokines cause functional and structural damage to isolated islets of Langerhans. Allergy 40: 424 429

4. Mandrup-Poulsen T, Bendtzen K, Nerup J, Egeberg J, Nielsen JH (1985) Mechanisms of pancreatic islet cell destruction: dose-dependent cytotoxic effect of soluble blood mononuclear cell mediators on isolated islets of Langerhans. Allergy (in press)

5. Brunstedt J (1980) Rapid isolation of functionally intact pancreatic islets from mice and rats by Percoll ${ }^{\mathrm{TM}}$ gradient centrifugation. Diabete Metab 6: 87-89

6. Heding L (1972) Determination of total serum insulin (IRI) in insulin-treated diabetic patients. Diabetologia 8: 260-266

7. Dinarello CA, Bernheim HA, Cannon JG, LoPreste G, Warner SJC, Webb AC, Auron PE (1985) Purified 35-S-methionine, 3-Hleucine labelled human monocyte interleukin-1 with endogenous pyrogen activity. Brit J Rheumatol 24: 59-64

8. Dinarello CA, Renfer L, Wolff SM (1977) Human leukocytic pyrogen: purification and development of a radioimmunoassay. Proc Natl Acad Sci (USA) 74: 4623-4627

9. Auron PE, Webb AC, Rosenwasser LJ, Mucci SF, Rich A, 
Wolff SM, Dinarello CA (1984) Nucleotide sequence of human monocyte interleukin-1 precursor cDNA. Proc Natl Acad Sci (USA) 81: 7907 -7911

10. Robb RJ, Kutny RM, Chowdhry V (1983) Purification and partial sequence analysis of human T-cell growth factor. Proc Natl Acad Sci (USA) 80: 5990-5994

11. Rhodes CJ, Taylor KW (1984) Effect of human lymphoblastoid interferon on insulin synthesis and secretion in isolated human pancreatic islets. Diabetologia 27:601-603

12. Dinarello CA (1984) Interleukin-1 and the pathogenesis of the acute-phase response. $\mathrm{N}$ Engl J Med 311: 1413-1418

13. Bendtzen K (1983) Biological properties of interleukins. Allergy 38: $219-226$

14. Giulian D, Lachman LB (1985) Interleukin-1 stimulation of astroglial proliferation after brain injury. Science 228: 497-499

15. Like AA, Forster RM, Woda BA, Rossini AA (1983) T-cell subsets in islets and lymphnodes of biobreeding/Worcester $(B B / W)$ rats. Diabetes 32: 201 (Abstract)

16. Sibley RK, Sutherland DER, Goetz FC, Michael AF (1985) Recurrent diabetes mellitus in the pancreatic iso- and allograft period. A light and electronmicroscopic and immunohistochemical analysis of four cases. Lab Invest 53:132-144

17. Debray-Sachs M, Boitard C, Assan R, Hamburger J (1981) Are "activated" macrophages cytotoxic against normal cells? Transpl Proc 13: 1111-1113

18. Schwizer RW, Leiter EH, Evans R (1984) Macrophage-mediated cytotoxicity against cultured pancreatic islet cells. Transplantation 37: $539-544$

19. Oschilewski U, Kiesel U, Kolb H (1985) Administration of silica prevents diabetes in BB-rats. Diabetes 34: 197-199
20. Nash JR, Everson NW, Wood RFM, Bell PRF (1980) Effect of silica and carrageenan on the survival of islet allografts. Transplantation 29: 206-208

21. Prud'homme GJ, Fuks A, Colle E, Seemayer TA, Guttmann RD (1984) Immune dysfunction in diabetes-prone BB-rats. Interleukin 2 production and other mitogen-induced responses are suppressed by activated macrophages. J Exp Med 159: 463-478

22. Zier KS, Leo MM, Spielman RS, Baker L (1984) Decreased synthesis of interleukin-2 (IL-2) in insulin-dependent diabetes mellitus. Diabetes 33: 552-555

23. Luger A, Schernthaner G, Luger TA (1985) Lymphokine production in insulin-dependent diabetes mellitus. Eur J Clin Invest 15: $1 \mathrm{~A}$ (abstract)

24. Arenzana-Seisdedos FM, Virelizier JL (1983) Interferons as macrophage-activating factors II. Enhanced secretion of interleukin 1 by lipopolysaccharide-stimulated human monocytes. Eur J Immunol 13: 437-440

25. Bonner-Weir S, Orci L (1982) New perspectives on the microvasculature of the islets of Langerhans in the rat. Diabetes 31: $883-889$

Received: 18 September 1985

and in revised form: 15 November 1985

J. Nerup

Steno Memorial Hospital

Niels Steensensvej 2

DK-2820 Gentofte

Denmark 